\title{
The Evolving Relationship between the Côa Valley Archaeological Park and the Local Community: an Account of the First Decade
}

\author{
António Pedro Batarda Fernandes, Marta Mendes, \\ Thierry Aubry, Jorge Sampaio, Rosa Jardim, Dalila \\ Correia, Ângela Jungueiro, Delfina Bazaréu, \\ FERnando Dias and PEDRo PINTO'
}

Côa Valley Archaeological Park, Portugal

The Côa Valley Archaeological Park (PAVC) reaches its 13th birthday in August 2009. Although the relationship between the Park and the local community has not always been unproblematic, the last few years have witnessed a major shift in the situation. While some misunderstandings still exist, recent efforts made by the PAVC, specifically enhancing education services involving local schools in heritage management and conservation, and in organizing activities aimed at the local population, have helped develop ties with the community.

KEYWORDS Rock art, Conservation, Local community, Education, Portugal

\section{Introduction}

The Côa Valley Archaeological Park (PAVC) will commemorate in August 2009 its $3^{\text {th }}$ birthday. Arising from the controversial atmosphere of its creation, the relationship with the local community has not always been without problems (Fernandes \& Pinto 2006). At the beginning of the I990s a large dam was to have been built in the Côa River: during construction a survey identified the first Côa rock art panels. Throughout 1994 and 1995 further engraved outcrops were discovered and the global archaeological community started to realize the importance of the findings being made in this far-off area of Portugal (Figure I). As international rock art specialists started to speak of the extraordinary aesthetical and scientific significance of the Côa rock art, Portuguese and international public opinion became interested in the subject. The issue sparked controversy: the dam, once finished, would flood most of the rock art sites, preventing them being seen by the public, and doubts were raised 


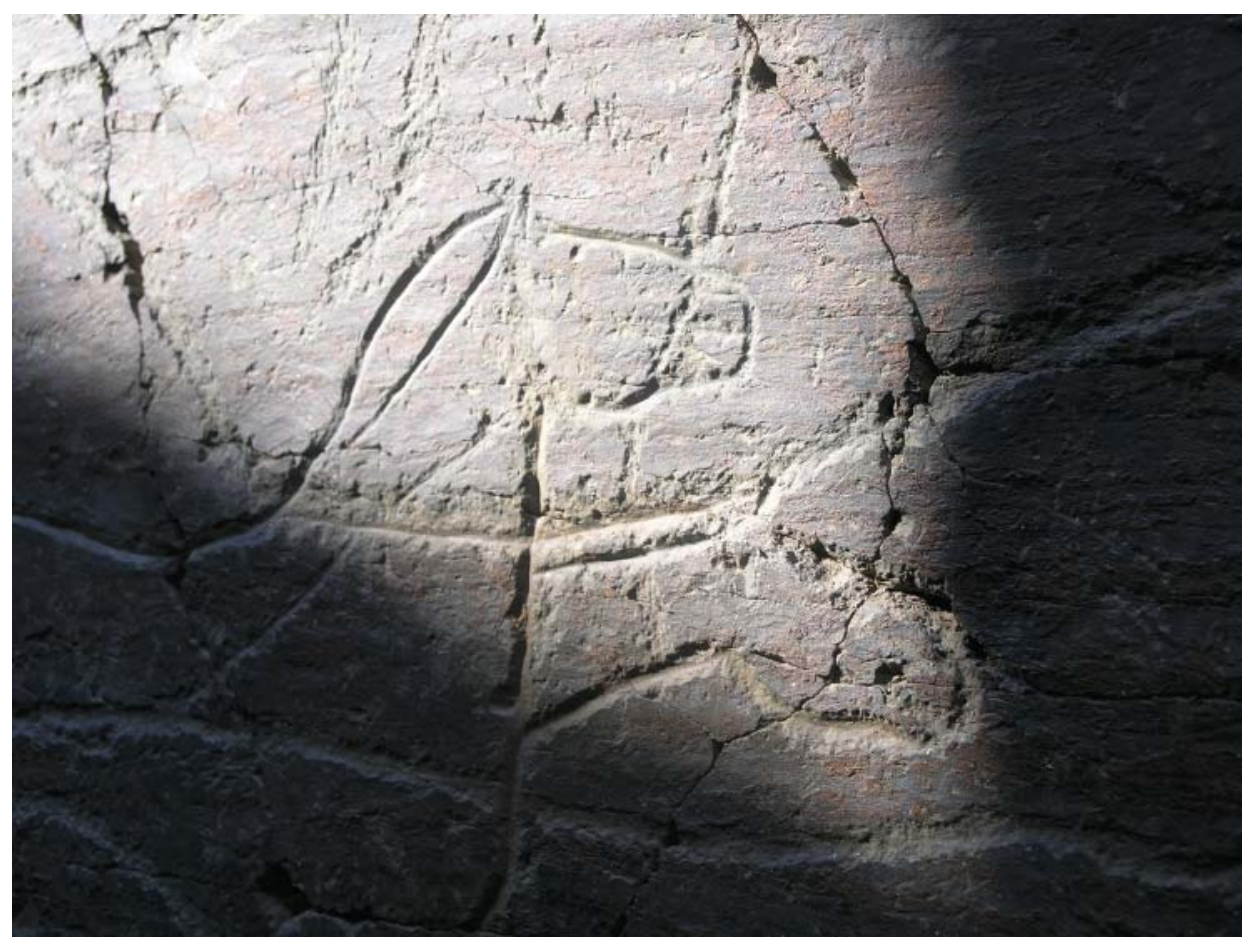

FIGURE 1 A two-headed horse at the Fariseu rock art site. The portrayal of two, or sometimes three, heads in a zoomorphic motif is one of the key characteristics of the Côa Valley rock art.

\section{Photograph by António Pedro Batarda Fernandes}

about their preservation after being covered by millions of hectolitres of water and mud. The result was an occasionally quarrelsome campaign to save the Côa Valley rock art that eventually split Portuguese public opinion into two distinct blocs. However, this was not the case with the local community: the vast majority of local inhabitants preferred, for reasons we shall discuss below, the construction of the dam.

Eventually, in 1996, the Portuguese government, acting on the advice of several international experts, decided to stop the dam's construction and create the PAVC. This option included substantial financial compensation for the Portuguese Power Company (EDP), the project developer. However, the judicious decision of the Portuguese Government would later prove its merit when UNESCO, in one of the fastest listing processes ever, in 1998 included the Côa Valley rock art sites on the World Heritage List (UNESCO I999). (There are numerous accounts of the Côa affair: see Zilhão I998; Baptista \& Fernandes 2007.)

While this paper reviews the way in which the relationship between the local community and the Park has evolved over this last decade, our main aim is to discuss what has been gained at the local level by the creation of the PAVC. We review some of the weaknesses in the process, but also some recent efforts to reach people in the community, creating more durable and effective (and even affective) ties with the rock 
art heritage. Despite a negative perception of the Park that appears periodically in Portuguese media (see Fernandes 2003), in our opinion the creation of the Park has brought many positive outcomes for the local community, for the region and for Portugal as a whole.

\section{An appraisal of benefits resulting from the creation of the PAVC}

When considering the relationship between the Park and the local community it is worth considering the Park's mission as legally established in the PAVC creation diploma, which states (article I3) that the PAVC must 'manage, protect and organise for public visits, including the setting up of museum facilities, the monuments included in the special protection zone of the Côa Valley' (Zilhão I998). Even though there are different views on how these responsibilities should be put into practice, the Park is legally bound to these objectives.

\section{Economic benefits}

The dam's construction would probably have resulted in money being injected into the local economy, mainly in the services area (restaurants, boarding houses and supermarkets) given the nearly 2,000 workers that, at peak construction time, would have come into the Foz Côa region. However, this economic growth would have been transitory since upon the dam's completion nearly all the workers would have left as few would have been from the sparsely populated Foz Côa area. After completion the dam would only provide a handful of jobs for local people. In contrast, the Park's establishment created 50 jobs (security guards, guides, archaeologists, administrative personnel, etc. - although the number of professionals working today in the PAVC has dropped to 45). The majority of the people hired were young professionals from the region. After the local municipality and schools, the Park is the biggest service sector employer in the region. For the municipality, located in the lightly populated interior of Portugal and with a total of 7,000 inhabitants, the employment provided by the Park makes a difference. In addition, the 45 employees live in the Foz Côa area, and their impact on the local economy is also not negligible.

Also important to the local economy are the number of tourists that in the last decade have visited the Park. Approximately I80,000 tourists visited the Park in the first II years (I996 to 2007), an average of c. 50 people per day, which has had a significant impact on the regional economy as visitors have to sleep and eat, and many buy souvenirs. If each visitor spent $c$. $€_{75}$ per day this would mean an annual visitor

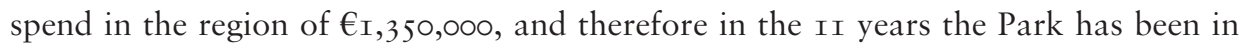
operation tourist spend in the Foz Côa region would have been around $€_{I_{5}}$ million. While not massive, this is a substantial contribution to the local fragile economy. Moreover, the number of tourists coming to Foz Côa in the last few years has generated a number of upgrades in the tourism facilities overall (new or refurbished restaurants, hostels, hotels, souvenir shops, etc.).

\section{Social benefits}

It can be argued that heritage and its preservation contributes to the strengthening of social cohesion by providing individuals in any given society with a sense of 
belonging and identity, in an increasingly global modern world. An affinity might be established with either the tangible or intangible features of old buildings, picturesque medieval villages or, in this case, archaeological sites such as the Côa, even if one visits such sites quite rarely. It is a common adage that societies without memory do not have a future, and the notion of the social value of heritage has already made its way into the public realm. ${ }^{2}$

In the case of the Côa Valley, the engravings have already become the region's brand, an image and notion that immediately identify Foz Côa as the place where prehistoric art exists. All over the town of Vila Nova de Foz Côa images of the engravings and concepts related to rock art imagery are widely used: in hostel logos, restaurant names, wine branding and labelling, and the local municipality and tourism welcoming billboards (Figure 2). More than just economically driven, these associations with the rock art imaginary suggest that an influential part of the local community — small business owners and local decision-makers — identify with the engravings, and furthermore want to be associated with the rock art itself. The Park's educational programme (discussed below), targeted at children and young people in the local community, is also an important tool in providing a sense of social cohesion.

\section{Cultural benefits}

The creation of the Park has contributed to the development of broader culture in the region. Often in partnership with the Mayor's office, the Park has organized art exhibitions, workshops, specialized courses on rock art, guide training, and gourmet events, in addition to the usual activities of the educational programme (see below). The Park also regularly publishes monographs on the region's heritage as well as specialized and general guides to the rock art sites.

The Park's creation was also important in raising regional awareness of general cultural heritage issues, such as preservation and conservation, the survival of ancient traditions, or valuing the often-underrated popular culture. ${ }^{3}$ The Park's ongoing research on the rock art and its archaeological context has also added to cultural development within the region.

\section{National benefits}

At a national level, the preservation of the Côa Valley and the creation of the Park also brought some benefits, including international recognition of the unprecedented decision to halt a major and costly dam project. Today the Côa is an important international research centre, used by international specialists in rock art management, protection and conservation. Favourable international exposure helped to raise the profile of Portugal, with benefits to the national tourism industry.

The Park's creation also contributed significantly to the development of archaeological research in Portugal: it set in motion a major reorganization of Portuguese archaeology that changed the way the discipline was perceived by both national public institutions and society in general. Archaeology is now seen as an important field of study and a contributor to land management issues, such as large infrastructure projects (Baptista \& Fernandes 2007). 


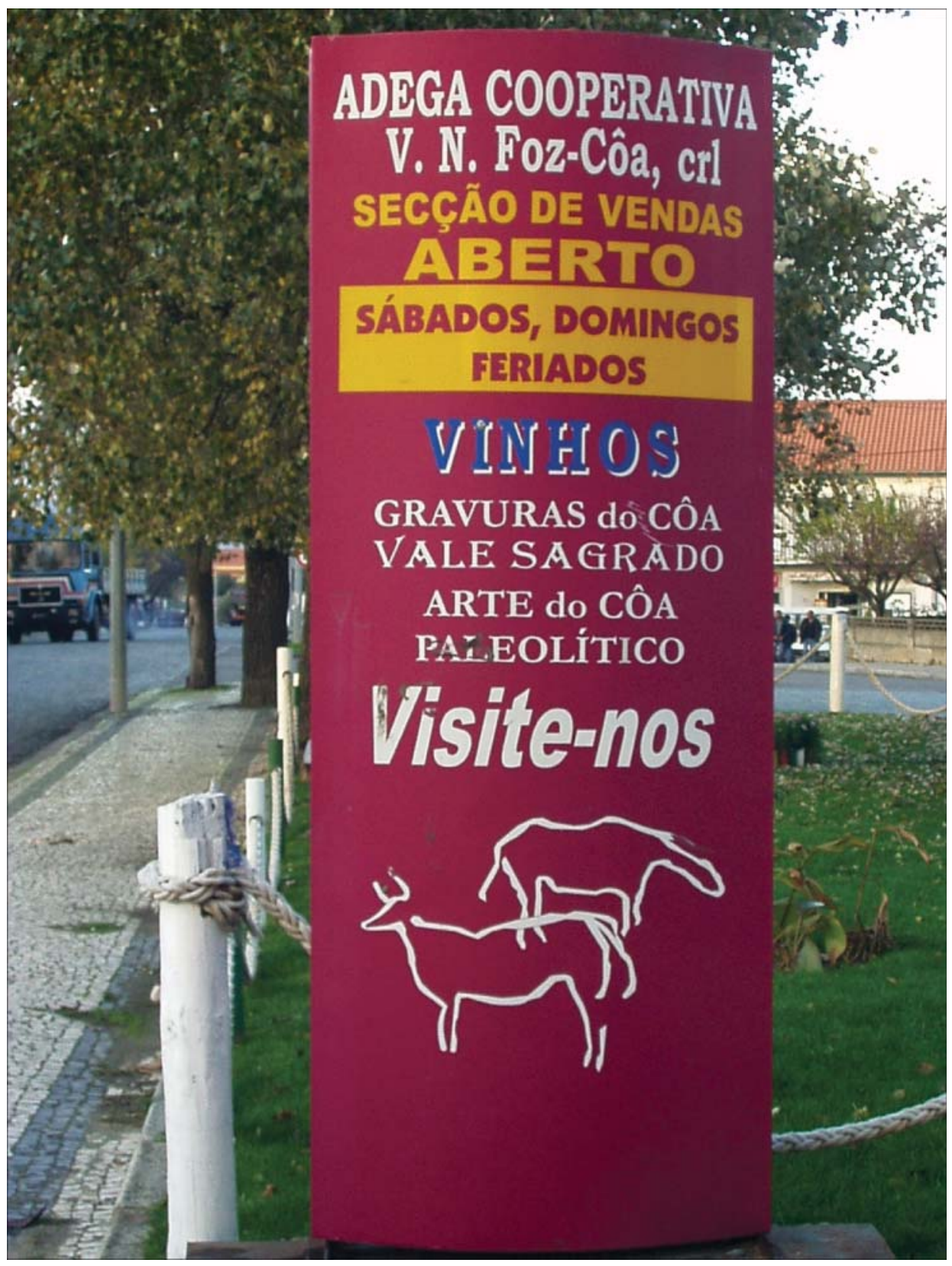

FIGURE 2 An advertising billboard for the Vila Nova de Foz Côa Wine Producers Cooperative. In addition to the use of the rock art imagery, notice the use of rock art related concepts in wine branding: 'Gravuras do Côa' (Côa Engravings); 'Vale Sagrado' (Sacred Valley); ‘Arte do Côa' (Côa Art); and, of course, 'Paleolítico'.

Photograph by António Pedro Batarda Fernandes 


\section{Weaknesses in the relationship}

Given the background from which the Park was created, it is not surprising that a great deal of resentment, and even animosity, existed towards the PAVC amongst the local community. Vila Nova de Foz Côa is situated in the underdeveloped interior of Portugal, an area that has been neglected for centuries by national governments based in Lisbon. The local community finally felt that it was to see some benefits (even if transitory, see above) from the construction of the dam, but the discovery of the rock art and the resultant halting of construction was considered a devastating blow. In the aftermath of the decision to preserve the rock art the local community, perhaps unconsciously, began to see the Park as the direct substitute for the dam: it wanted the scale of economic development that would have resulted from the dam construction to be delivered, in a short timescale, by the PAVC; something that was quite impossible.

Another factor that contributed to an atmosphere of mistrust was that a governmental funding agency, called PROCOA, set up specially to help develop the local economy, was located in the same building as the Park's main office. Even though PROCOA and the PAVC were two distinct institutions (although actively collaborating), with different missions, the local community often regarded the two as being the same. As it transpired, PROCOA was underfunded (Fernandes 2003) and failed to meet local expectations, further damaging the relationship between the Park and the community.

There were also some difficulties in communication between the Park and the local community, largely due to different expectations regarding the rock art and the way it was to be managed. The local community expected to see tangible and visible benefits (economic, if you will) from the creation of the Park, while the PAVC sought a balanced and sustainable equilibrium between public access to the rock art and conservation, to ensure its continued existence within a landscape context. As a result, elements of the local community felt that the public access system was too restrictive and did not meet their overall development needs. It was suggested that at least one of the rock art sites should be 'sacrificed': that is, opened to the public without any restriction. The Park is very cautious about any redesign of the visitation scheme. ${ }^{4}$

The Park's general response was to try to ignore the controversial background, in order to let time heal some of the wounds and allow the results of its long-term conservation and development programmes to become palpable. As a result, in the first few years, the dialogue between the PAVC and the local community, especially the official local authorities such as the municipality, was often problematic and, for the most part, unproductive. The Park's position was considered arrogant and the local community reacted with some hostility, seeing the Park's higher officials as big city professionals who had come to the province to show them how to run their lives.

The past atmosphere of mistrust and poor communication has been synthesized in a paper written in 2002, briefly revised and updated in 2005 , and published in 2006 (Fernandes \& Pinto 2006). In that paper we defended as entirely justifiable the Park's stance of trying to ignore the controversy. However, by the middle of 2008 , when the current paper was being written, the relationship between the Park and the 
local community had evolved considerably: there had been a shift in the local community's feelings regarding the role of the Park in the management of the rock art sites. Perhaps concepts of sustainable cultural management are beginning to be accepted, but probably more influential is the construction of the Côa Valley Rock Art and Archaeology Museum, scheduled to open in late 2009, which will enlarge significantly the PAVC's ability to receive tourists. The Museum will enable visitors, especially those who have not been able to book one of the limited places on the rock art site tours, to experience an overview of the Côa Valley rock art. As such, the Museum is expected to play a major part in the development of tourism in the area. Although some disagreements still exist, the atmosphere of mistrust has been almost completely swept way. The greater part of the local community now sees the Park as an invaluable partner in achieving a common goal: that of developing, in a sustainable fashion, regional tourism overall, with the rock art sites as the main attraction.

\section{Recent efforts to reach the community}

Instrumental to this change in attitude was the development of a new attitude on the part of the Park in actively trying to engage with the local community. Activities have focused on three, often interrelated, lines of action:

I. improving the relationship between the Park and other local and regional public services

2. improving the relationship between the Park and the community

3. establishing solid links between the Park and local schools.

\section{Collaboration with local and regional public services}

A number of protocols have been established with local and regional public services, such as institutions focused on agricultural or riverside management, and with cultural and socio-economic development agencies. Examples of the actions carried out include: the installation of wooden piers on the river, next to the rock art sites open to the public, to allow for boat visits; establishing new shared approaches to better manage, protect and preserve local heritage features such as landscapes, monumental buildings, vernacular architecture, traditional crafts, etc.; and developing partnerships with the regional branch of the government employment agency.

\section{Collaboration with regional town and borough councils}

The partnerships with regional municipalities encompassed several kinds of activities, for example: major scientific conferences were organized; experimental archaeology workshops were undertaken in many towns and villages; open sessions for the local population were organized on management and protection issues (structured to enable broad debate on heritage protection and land management issues, so that community views could be considered when planning and implementing the Park's policies); numerous talks, presentations and traditional music concerts were organized; and the Park assisted the local administration in preparing conservation interventions on local monuments such as churches, traditional architecture in villages, etc. 


\section{Collaboration with local environmental, cultural and heritage protection associations}

The Park engaged in partnerships with private sector associations and nongovernmental organizations (NGOs). An example was the development of protocols with Transumância (an environmental association) to fight summer fires better, to keep the rock art sites clean and tidy, and to develop a management plan specially designed to protect the Côa Valley's natural environment. Protocols were also signed with heritage protection associations to enhance further the tourist-orientated guides to the region, and the Park also collaborated with the regional hunting and fishing associations in order to establish more rules to manage the impact of those activities on the environment and the archaeological landscape.

On the cultural level, the Park assisted in organizing art exhibitions at a national and even international level, the most important of which was perhaps the $I V$ International Douro Gravure Biennial. Other partnerships were developed with cultural NGOs such as LuzLinar and Fundação Morais Sarmento, enabling numerous exhibitions to be put on throughout Portugal, which greatly contributed to disseminating information about the Côa Valley. In addition, the CHUKAS project is attempting to recreate Upper Palaeolithic music and the Park is sponsoring the forthcoming CD.

\section{Visits for local residents}

In order to strengthen the rapport between the local community and the rock art, special free of charge visits for the local population have been conducted. The PAVC organized the open days through local interest groups: one open day was only for restaurant owners/managers, another was focused on tourist accommodation owners, another for wine producers, etc. Many of these activities were enhanced by visits to wine producing farms. (Special local schools activities and visits to the rock art sites are described below.)

\section{Promoting contact between visitors and residents}

On the Park's important anniversaries (such as its creation, or the inscription on to the World Heritage List) special commemoration programmes are organized in order to foster the interaction of visitors and local residents. Such programmes include concerts, exhibitions, talks, wine and local food tasting, and experimental interpretations of Upper Palaeolithic meals.

\section{Specific training}

Seven training courses were developed in a partnership between the Park, the state employment agency and a private company. The courses included: training new guides; the first experimental archaeology courses in Portugal; traditional pottery manufacture; and cultural entrepreneurship. These courses were aimed at a young disadvantaged adult audience and their main objective was to provide them with the tools to help them create their own jobs.

\section{Enhancing the Park's educational programme}

Although it has been in a continuous process of development for several years, the PAVC educational programme has achieved only recently a strong connection with 
local and regional schools. Actions specially targeted at school communities (see below) have gradually become part of the regular curricular activities. The relative success of the educational programme can be measured by the fact that in the 2004/05 school year, before the first Education Action Plan was implemented, only 97I students visited the Park as part of school visits. In the following year (2005/06), the strategies set out in the PAVC's educational plan nearly tripled the number of students visiting the Park, to 2,863 (Mendes 2008). The flexible nature of the Park's educational programme is perhaps one of its key characteristics, as activities can be customized to different institutional needs and undertaken in diverse locations.

The Park's educational programme is vital in raising awareness of the complex issues of heritage management. Hopefully a strong empathy can be established with the rock art and its surrounding landscape at an early stage, and this will help to ensure that future generations will continue to preserve and protect heritage values, both at local and national levels.

\section{'The Côa in the school'}

'The Côa in the School' project aims to improve the relationship between local youngsters and the Park by organizing regular visits to the rock art sites for students and teachers (Figure 3). These special visits have a thematic nature, covering issues

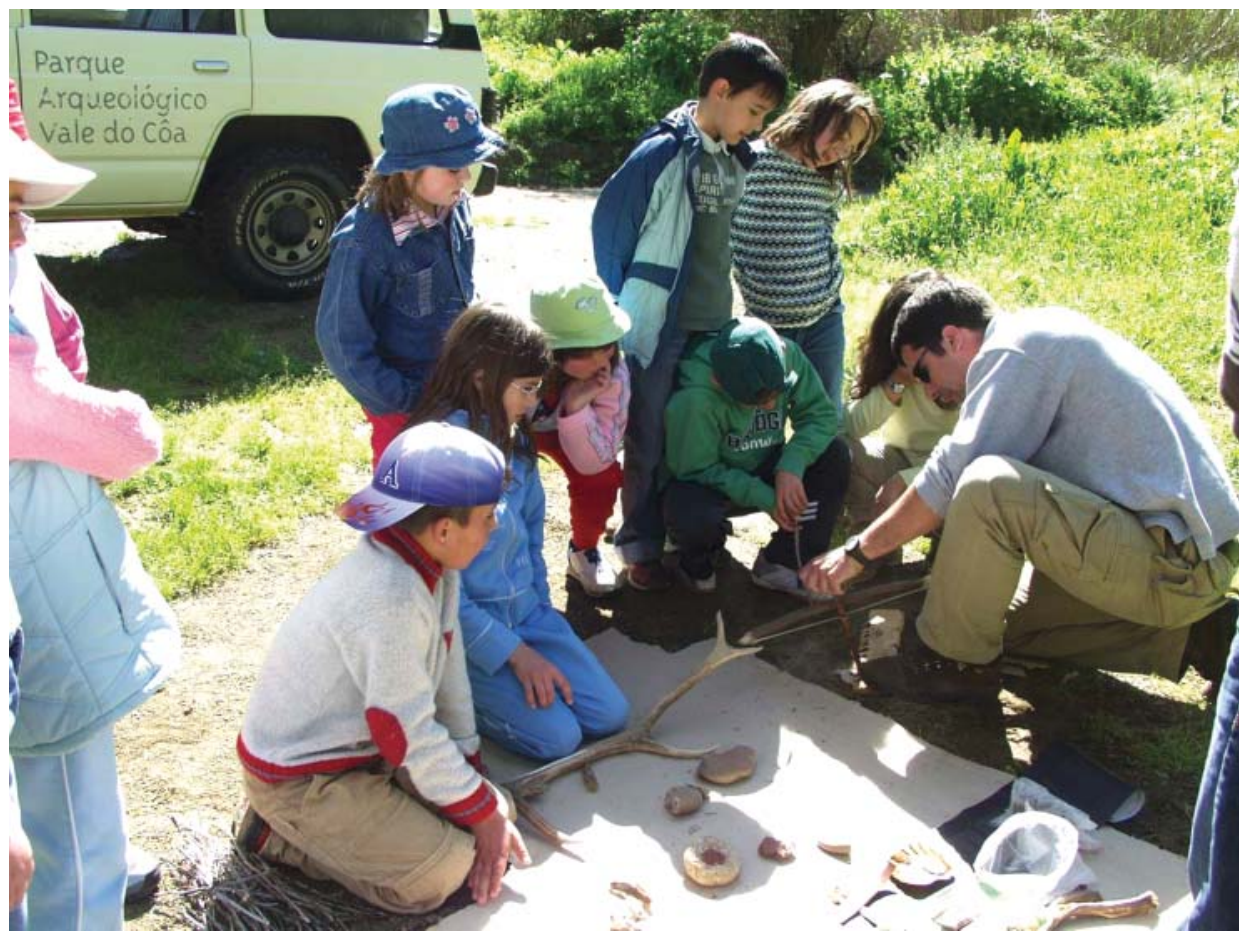

FIGURE 3 Experimental archaeology workshop for elementary school students, taking place at the Penascosa rock art site. One of the authors (Pinto) demonstrates how Upper Palaeolithic hunter-gatherers may have produced fire.

Photograph by Rosa Jardim 
such as local heritage, archaeology, biology, and geology. In addition to Park staff, other local professionals, working for organizations such as the Mayor's office or local NGOs, take part in the visits, explaining specific areas of knowledge (for example, local biological systems or the geological features).

\section{Activities during school holidays}

During school holidays the Park created, in close collaboration with local education institutions, specific activities aimed at occupying students' spare time and engaging youngsters pedagogically with the rock art heritage and its context. These activities take place outdoors, at the rock art sites and in the surrounding environment, and indoors at the Park's main office. They include hands-on experiments, educational games, and workshops.

\section{Workshops}

Workshops have been specifically developed for local students, although they are also available to all Park visitors on request. Workshop activities have been created taking into consideration the age of visiting students and the different profiles of general visitors. The most popular has been an experimental archaeology workshop, which has been established to explore our ancestors' way of life, in a vibrant and interactive form (Figures 4 and 5). Activities in which students participate include painting and

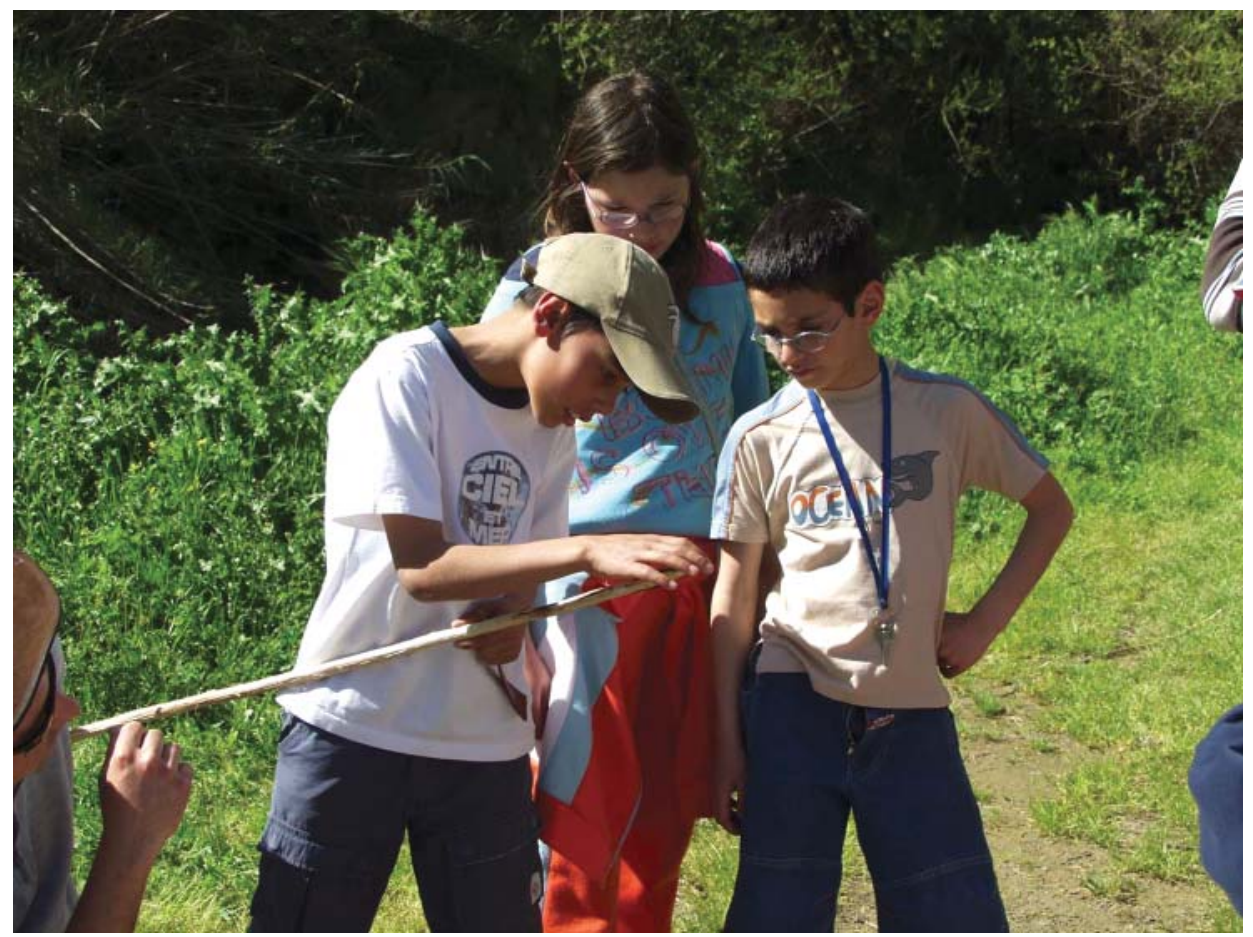

FIGURE 4 During an elementary school workshop at the Penascosa rock art site, one of the students feels the weight and sharpness of a spear.

Photograph by Rosa Jardim 
engraving, and re-enacting prehistoric daily activities (such as hunting and tool production). These workshops are offered to all the schools that visit the Park, with the only requirement being advance booking to allow sufficient time to prepare the activities. On request, it has also been possible to present these workshops in other educational institutions in the region. Workshops are often complemented by a visit to the rock art sites.

\section{Additional activities for schools visiting the Park}

An activity sheet has been created to help prepare schools for a visit to the rock art sites. The sheet (which can be downloaded from the PAVC's website at www.ipa. min-cultura.pt/coa) is adapted to different learning levels and includes not only activities connected with disciplines such as History and Archaeology, but also Geography, Environmental Studies, Art, etc.

\section{Expanding the Park's visitor activities}

The expansion of the PAVC's visitor activities, although not specifically targeted at strengthening the relationship with the local community, has actually played a significant role in changing the perception of the local population towards the Park.

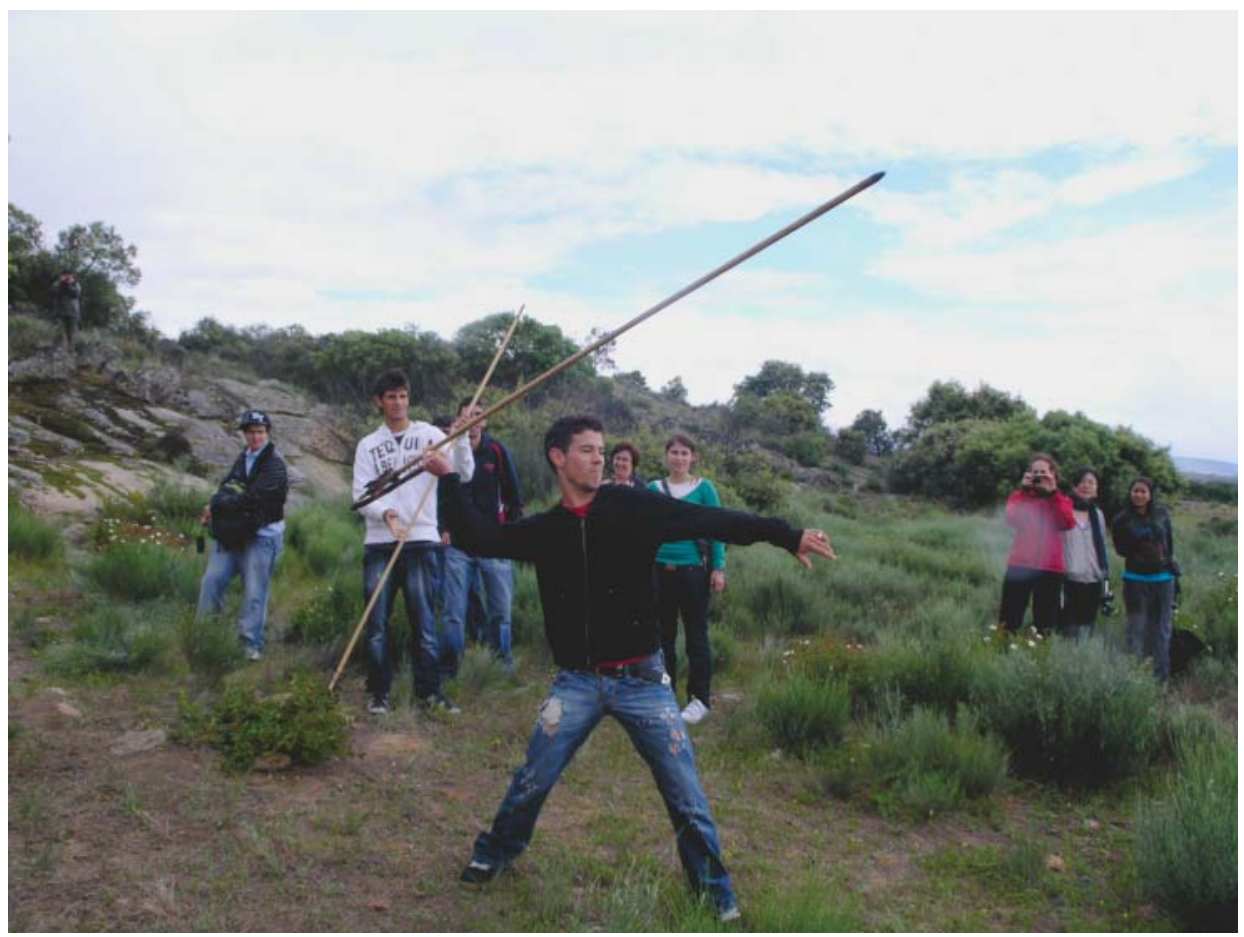

FIGURE 5 At an experimental archaeology workshop high school students try their spear hunting skills, with the help of a thrower.

Photograph by António Pedro Batarda Fernandes 


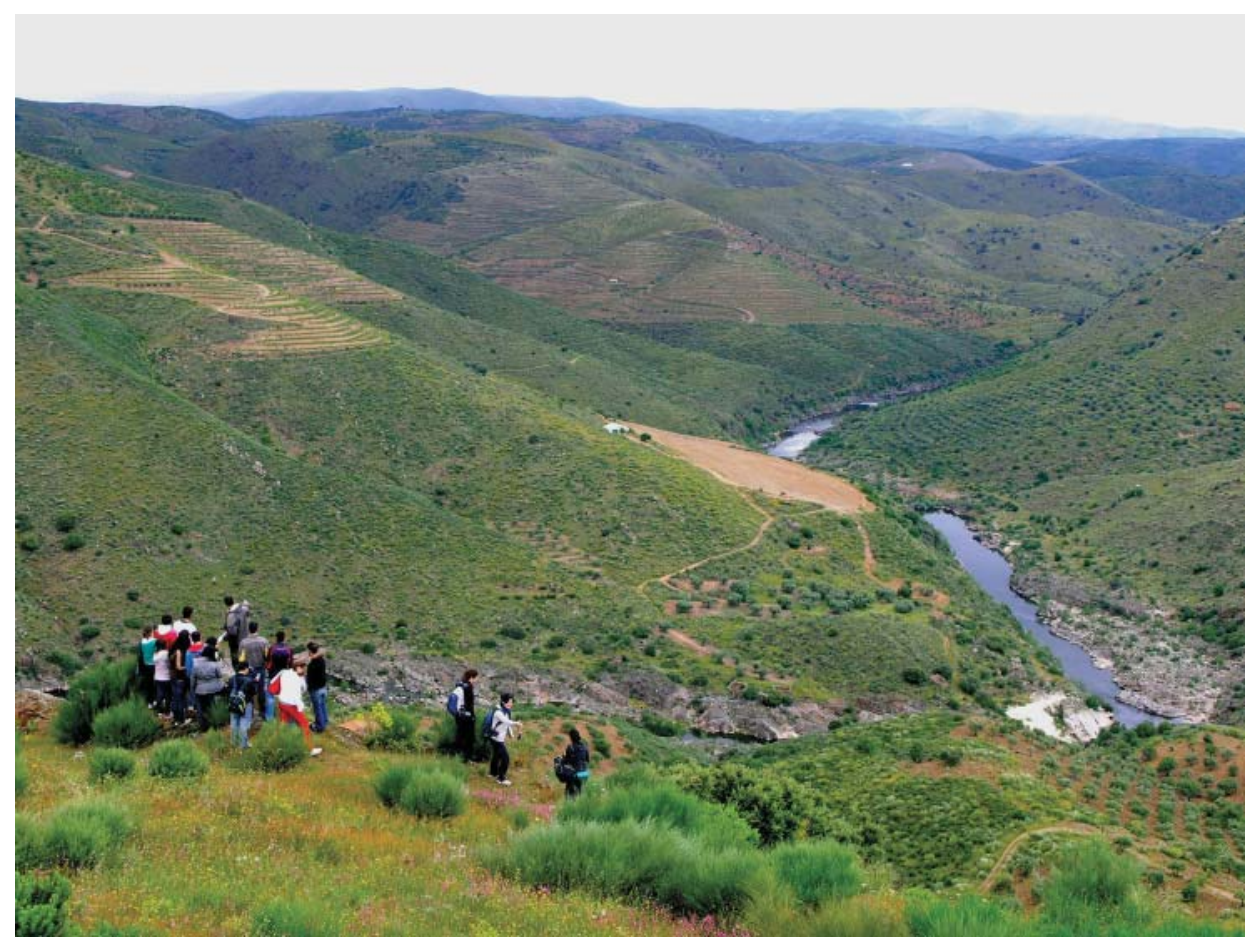

FIGURE 6 The start of an organized walk 'On the trail of the Palaeolithic hunters', overlooking the Côa Valley.

Photograph by António Pedro Batarda Fernandes

The local community have reacted favourably to the PAVC's efforts in attracting more visitors to the area, including new types of visit (such as a night-time visit to the Penascosa rock art site, or a walk that follows the trail of Upper Palaeolithic hunters through identified habitat sites) (Figure 6).

\section{Conclusion}

This last decade has witnessed major shifts in the relationship between the Park and the local community. The relationship is not perfect, but the Park, the local stakeholders involved (either directly or indirectly) with the management, conservation and public presentation of the Côa Valley rock art, and the local community have evolved together. All have tried to find common ground, from where it is possible to continue building the region's shared future. We believe that the Park's fresh attitude, together with a more sympathetic attitude on the part of the local community, has played a considerable role in this evolution. It is not possible for the Park to exist in isolation from its socio-economic context: in the long term, a sustainable future for the rock art will depend, to a great extent, on the success of the Park's efforts in reaching the local community. The goal is to make the local population an active partner in the management, preservation and conservation of the Côa Valley heritage as a whole, and a key player in regional sustainable development. 
In a paper written in 2002, for the World Archaeological Congress, but only published in 2006 , we stated:

Agreeing with Liwieratos (2004) when she says that, 'there is a greater chance of achieving sustainable conservation through development if responsibilities are shifted to the public' we nevertheless believe that it is vital to make sure that the local community is truly prepared to deal wisely with the responsibility of contributing decisively to the management of a World Heritage Site. (Fernandes \& Pinto 2006, I42)

The last few years have shown that heritage can be a part of everyday life; it can be 'alive', not just 'old things' with no connection to contemporary communal interests. The last decade has also demonstrated that, with the right kind of public-orientated strategies, we can be optimistic as to the future commitment of the local community to the protection of the Côa Valley heritage.

\section{Notes}

I Although António Pedro Batarda Fernandes wrote this paper, nine PAVC professionals are included as co-authors as the activities described here are the result of the work and commitment of all.

2 The Portuguese President, Cavaco Silva, stated 'Portugal will only be a truly modern country if it is a country with memory' (Silva 2008, author's translation).

3 One of the training courses (discussed under educational activities) attempted to address the survival of the regional pottery-making tradition, which is doomed to disappear if young people are not able to learn traditional techniques from existing masters.
4 Visitors to the Park have reacted very favourably to the restrictive visitation scheme in place (a maximum of 130 visitors per day to the three open rock art sites). Results from an unpublished visitor survey undertaken in 2007 , coordinated by two of the authors (Fernandes and Junqueiro), reinforced the findings of previous surveys (Fernandes 2003) which showed that the visitor experience had an overall approval rate of around 90 per cent, and some 95 per cent of the visitors said they would recommend the visit to friends and family. For a more detailed discussion of the issues related to the visitation scheme, see Fernandes 2003.

\section{Bibliography}

Baptista, A M \& Fernandes, A P B 2007 Rock art and the Côa Valley Archaeological Park: a case study in the preservation of Portugal's prehistoric parietal heritage, in P Pettitt, P Bahn \& S Ripoll (eds) Palaeolithic cave art at Creswell Crags in European context. Oxford: Oxford University Press, 263-79.

Fernandes, A P B 2003 Visitor management and the preservation of rock art: two case studies of open air rock art sites in north-eastern Portugal: Côa Valley and Mazouco, Conservation and Management of Archaeological Sites 6, 95-III.

Fernandes, A P B \& Pinto, F M 2006 Changing stakeholders and community attitudes in the Côa Valley, Portugal, in $\mathrm{N}$ Agnew \& J Bridgland (eds) Of the past, for the future: integrating archaeology and conservation. Los Angeles: Getty Conservation Institute, ${ }_{13} 6-42$.

Liwieratos, K 2004 Introducing the competitive advantage theory/strategy in heritage management, Public Archaeology 3, 227-39.

Mendes, M 2008 Um discurso pedagógico para a arte rupestre do Vale do Côa: o processo de criação do serviço educativo, Turismo and Desenvolvimento 9, $154-9$.

Silva, A C 2008 Intervenção do Presidente da República na Universidade de Coimbra. Coimbra, 2 I de Janeiro de 2008. Available: http://www.presidencia.pt/?idc=27\&idi=I250I [Accessed 28 May 2008].

UNESCO 1999 Report on the twenty-second session of the World Heritage Commission. Kyoto, Japan. 30 November-5 December 1998. Paris: World Heritage Commission.

Zilhão, J 1998 The rock art of the Côa Valley, Portugal: significance, conservation and management, Conservation and Management of Archaeological Sites 2, I93-206. 


\section{Notes on Contributors}

António Pedro Batarda Fernandes was until December 2007 the Park's archaeologist coordinating the Conservation Programme. In February 2008 he started a $\mathrm{PhD}$ course at Bournemouth University.

Marta Mendes is a Park archaeologist, responsible for the coordination of the PAVC's Educational Programme.

Thierry Aubry is a Park archaeologist, responsible for the research of the Côa Valley Upper Palaeolithic archaeological context and the organization of the experimental archaeology workshop.

Jorge Sampaio is a Park archaeologist, involved in the study of the Côa Valley Upper Palaeolithic archaeological context and in the organization of the experimental archaeology workshop.

Rosa Jardim is a Park archaeologist, responsible for the coordination of the PAVC's Educational Programme.

Dalila Correia is a Park archaeologist, researching the Côa Valley rock art.

Ângela Junqueiro is a Park guide, responsible for visitor surveys and tourism development.

Delfina Bazaréu is a Park guide, responsible for liaison with the local community and coordinating local community visits to the PAVC.

Fernando Dias is a Park guide, responsible for liaison with local NGOs, hunting and fishing associations, and coordinating local community visits to the PAVC.

Pedro Pinto is a Park guide, responsible for the presentation of the experimental archaeology workshop.

Correspondence to: António Pedro Batarda Fernandes, Côa Valley Archaeological Park, Av. Gago Coutinho, ı9A, 5I50-6ı Vila Nova de Foz Côa, Portugal. Email: batarda@hotmail.com 